Cochrane Database of Systematic Reviews

\title{
Gene therapy for haemophilia (Review)
}

Sharma A, Easow Mathew M, Sriganesh V, Reiss UM

Sharma A, Easow Mathew M, Sriganesh V, Reiss UM.

Gene therapy for haemophilia.

Cochrane Database of Systematic Reviews 2016, Issue 12. Art. No.: CD010822.

DOI: 10.1002/14651858.CD010822.pub3.

www.cochranelibrary.com 
HEADER 1

ABSTRACT

PLAIN LANGUAGE SUMMARY

BACKGROUND

OBJECTIVES

METHODS

Figure 1.

RESULTS

DISCUSSION

AUTHORS' CONCLUSIONS

ACKNOWLEDGEMENTS

REFERENCES

APPENDICES

WHAT'S NEW

CONTRIBUTIONS OF AUTHORS

DECLARATIONS OF INTEREST

SOURCES OF SUPPORT

INDEX TERMS

\section{TABLE OF CONTENTS}


[Intervention Review]

\section{Gene therapy for haemophilia}

Akshay Sharma ${ }^{1}$, Manu Easow Mathew² ${ }^{2}$ Vasumathi Sriganesh ${ }^{3}$, Ulrike M Reiss ${ }^{4}$

1St Jude Children's Research Hospital, Memphis, Tennessee, USA. ${ }^{2}$ South Asian Cochrane Network \& Center, Prof. BV Moses Center for Evidence-Informed Health Care and Health Policy, Christian Medical College, Vellore, India. ${ }^{3}$ QMed Knowledge Foundation, Mumbai, India. ${ }^{4}$ Hematology Department, St Jude Children's Research Hospital, Memphis, Tennessee, USA

Contact address: Akshay Sharma, St Jude Children's Research Hospital, 262 Danny Thomas Place, MS 260, Memphis, Tennessee, 38105, USA.mail@akshaysharma.in, akshay.sharma@stjude.org.

Editorial group: Cochrane Cystic Fibrosis and Genetic Disorders Group.

Publication status and date: New search for studies and content updated (no change to conclusions), published in Issue 12, 2016.

Citation: Sharma A, Easow Mathew M, Sriganesh V, Reiss UM. Gene therapy for haemophilia. Cochrane Database of Systematic Reviews 2016, Issue 12. Art. No.: CD010822. DOI: 10.1002/14651858.CD010822.pub3.

Copyright @ 2016 The Cochrane Collaboration. Published by John Wiley \& Sons, Ltd.

\section{A B S T R A C T}

\section{Background}

Haemophilia is a genetic disorder characterized by spontaneous or provoked, often uncontrolled, bleeding into joints, muscles and other soft tissues. Current methods of treatment are expensive, challenging and involve regular administration of clotting factors. Gene therapy has recently been prompted as a curative treatment modality. This is an update of a published Cochrane Review.

\section{Objectives}

To evaluate the safety and efficacy of gene therapy for treating people with haemophilia A or B.

\section{Search methods}

We searched the Cochrane Cystic Fibrosis \& Genetic Disorders Group's Coagulopathies Trials Register, compiled from electronic database searches and handsearching of journals and conference abstract books. We also searched the reference lists of relevant articles and reviews.

Date of last search: 18 August 2016.

\section{Selection criteria}

Eligible trials include randomised or quasi-randomised clinical trials, including controlled clinical trials comparing gene therapy (with or without standard treatment) with standard treatment (factor replacement) or other 'curative' treatment such as stem cell transplantation for individuals with haemophilia A or B of all ages who do not have inhibitors to factor VIII or IX.

\section{Data collection and analysis}

No trials of gene therapy for haemophilia were found.

\section{Main results}

No trials of gene therapy for haemophilia were identified.

\section{Authors' conclusions}

No randomised or quasi-randomised clinical trials of gene therapy for haemophilia were identified. Thus, we are unable to determine the safety and efficacy of gene therapy for haemophilia. Gene therapy for haemophilia is still in its nascent stages and there is a need for welldesigned clinical trials to assess the long-term feasibility, success and risks of gene therapy for people with haemophilia. 


\section{PLAIN LANGUAGE SUMMARY}

\section{Gene therapy for haemophilia}

\section{Review question}

We reviewed the evidence about the safety and effectiveness of gene therapy for treating people with haemophilia A or haemophilia B.

\section{Background}

Haemophilia is a bleeding disorder caused by defective genes that produce abnormal blood clotting proteins. Gene therapy modifies or replaces these defective genes with normal ones. We looked for trials that used this approach of modifying or replacing defective genes for producing normal blood clotting proteins for the treatment of haemophilia. This is an update of a published Cochrane Review.

\section{Search date}

The evidence is current to: 18 August 2016.

\section{Key results}

We found no trials to provide reliable evidence about the risks or benefits of gene therapy for haemophilia. There is a need for trials that assess the long-term feasibility, success and risks of gene therapy for people with haemophilia. 


\section{B A C K G R O U N D}

\section{Description of the condition}

Haemophilia is an X-linked bleeding disorder characterized by spontaneous or provoked, often uncontrolled, bleeding into joints, muscles and other soft tissues, causing significant pain, swelling and permanent damage if left untreated. Haemophilia is caused by a genetic deficiency of specific proteins in the blood called clotting factors. Haemophilia A is caused to an inherited deficiency of factor VIII and haemophilia B is caused to a deficiency of factor IX. The incidence of haemophilia A is around 1 per 5000 to 10,000 male births, and about 1 per 60,000 male births for haemophilia B. Approximately $80 \%$ of affected children are born deficient in factor VIII (haemophilia A) and $20 \%$ are deficient in factor IX (haemophilia B) (Bi 1995; Wong 2011). Haemophilia is inherited in an X-linked recessive manner. Hence, haemophilia occurs almost exclusively in males, but can also occur in some carrier females due to variances in inactivation of $X$ chromosomes.

The goal, when managing these patients, is to control both the frequency and severity of bleeding episodes and ultimately to prevent permanent joint damage and death in severe cases. Replacement of the missing clotting factor from exogenous sources is the mainstay of therapy in haemophilia. Before World War II, treatment of haemophilia was limited to the transfusion of whole blood or fresh plasma. The first clotting factor concentrate was discovered in the 1960s in the form of cryoprecipitate. In the late 1960 s, plasma-derived clotting factors were isolated which created a paradigm shift in the management of haemophilia (Brinkhous 1968; Webster 1965). By 1980, the commercially available freezedried factor VIII and IX concentrates increased the average lifespan of people with haemophilia from a mere 27 years in the 1940s to 60 years (Evatt 2006; Wong 2011). Early factor VIII and IX concentrates were derived from pooled human plasma from up to 20,000 donors.

Although hepatitis B and C were known risks of pooled human serum derived factor concentrates, they were considered acceptable due to a drastic improvement in the quality of life of people with haemophilia (Kasper 1972; Makris 1990; Mannucci 1977). In 1982 came the first reports of people with haemophilia succumbing to acquired immune deficiency syndrome (AIDS) and only later it was realized that plasma-derived factor concentrates were responsible for transmission of the still unidentified infectious agent (Aronstam 1993; Gill 1983; Goedert 1989). Nearly 90\% of Americans with severe haemophilia were reported to be infected with HIV in the 1980s via contaminated pooled serum products (NHF 2013). HIV was isolated in early 1984 and by early 1985 heating of factor concentrates became standard practice to kill the virus before transfusion (Wong 2011). Subsequently, several safeguards were employed to prevent donor derived factor transfusion induced infections, such as: donor screening; chromatographic purification; and viral inactivation (Wong 2011). Fortunately, since 1986, there have been no reported cases of HIV transmission through factor concentrates at least in the USA (NHF 2013). The human factor IX gene was cloned in 1982, followed by the production of human rFIX in Chinese hamster ovary cells (Anson 1984; Choo 1982). Factor VIII was cloned and sequenced in 1984 (Gitschier 1984; Toole 1984) and the first recombinant factor VIII (rFVIII) product was approved for clinical use in 1992 (Wong 2011).

The initial treatment modality was episodic or 'on demand' replacement of the missing factor as needed, after the onset of bleeding. However, several studies have shown that prophylactic administration of clotting factor concentrates to prevent bleeding episodes preemptively is more beneficial than episodic administration (Iorio 2011; Manco-Johnson 2007) The goal of clotting replacement is to keep factor activity greater than $1 \%$. The currently used adjuvant therapies include the use of antifibrinolytic agents (in both haemophilia A and B) and desmopressin (in mild and moderate haemophilia A only). The antifibrinolytic agents such as e-aminocaproic acid and tranexamic acid exert their effect by inhibiting the proteolytic activity of plasmin and, therefore, inhibiting fibrinolysis (Wong 2011). Desmopressin works mainly by releasing von Willebrand's factor from its storage sites and stabilizing the already present factor VIII in the plasma (Castaman 2008; Leissinger 2001).

\section{Description of the intervention}

It was first shown in 1989 that human factor IX could be synthesized and secreted into the circulation of laboratory animals after transplantation of genetically modified human fibroblasts using a human factor IX CDNA containing retrovirus (Nathwani 2004; Palmer 1989). Since then, several translational approaches have been developed for the clinical application of gene therapy in haemophilia, but most of these only resulted in transient benefits (Manno 2003; Manno 2006; Powell 2003; Roth 2001; VandenDriessche 1999; Xu 2003). Finally, in 2011, a new adenoassociated virus (AAV) vector for factor IX gene transduction that could directly be given to an adult by a peripheral vein infusion was developed (Nathwani 2006; Nathwani 2011; Tuddenham 2012; Nathwani 2014).

Gene therapy is not without risk. The introduction of new genetic material via vector viruses may cause unpredictable outcomes due to the alteration of the host genetic material (insertional mutagenesis) (Hacein-Bey-Abina 2003; Miller 2005; Nakai 2005). There is a theoretical risk that the viral vector may regain its potential to produce new viral particles, or may cause harmful immune reactions (High 2011; Manno 2003; Mingozzi 2011). Also of concern is the development of neutralizing antibodies to factor VIII or IX after gene therapy and it may render the gene product futile in such patients. Lastly, T-cell mediated immune response by the immunocompetent host against the transgene, its product proteins, or the viral capsid which may be expressed on the host cells, can be potentially harmful for the recipients of the gene therapy (Nathwani 2011; Nathwani 2014). All these potential adverse effects, as well as the long-term safety of gene therapy are yet to be evaluated in a large cohort.

\section{How the intervention might work}

The currently available standard treatment for haemophilia is lifelong clotting factor replacement, a regimen that is both expensive and is not easily available in several countries (Iorio 2011; Ponder 2008). Worldwide, about $75 \%$ of haemophilia patients do not have access to adequate care (Ponder 2008; WFH 2013). Due to the short half-life of the clotting factors in the blood, replacement is required usually every other day for haemophilia $A$ and every two to three days for haemophilia B. The frequency and mode of administration (intravenous (IV)) of these treatments poses a wide range of challenges to people affected with haemophilia and their families (need for IV catheters and related complications such as infections and thrombosis) (Santagostino 2010). 
At USD 1 per unit of recombinant factor VIII, the annual cost of on-demand factor replacement therapy for a single $50 \mathrm{~kg}$ adult patient of haemophilia is USD 150,000 in the United States of America (Manco-Johnson 2007; Ponder 2011). This cost increases to about USD 300,000 for prophylactic therapy. This amounts to an individual lifetime cost of over USD 20 million in factor replacement costs alone (Ponder 2011). Such an exorbitant therapy is neither available frequently, nor affordable to almost $75 \%$ of the people with haemophilia in the world who live in low- and middle-income countries (Ponder 2008; Ponder 2011; WFH 2013). These individuals continue to have significant morbidities and die young.

In comparison to the above treatment modalities, gene therapy holds substantial promise. The key advantage being that potentially a one time intervention can be permanently curative. This intervention will lead to complete avoidance of the need for IV infusions, reduced hospital visits, a decrease in the use of other interventions and their side effects and ultimately reduced costs (Nathwani 2011; Nathwani 2014). The commercial cost of gene therapy using the viral vector is projected at USD 30,000 per patient (Ponder 2011). Such a therapy would be life changing for people with haemophilia.

\section{Why it is important to do this review}

Gene therapy holds significant promise of a substantially better treatment modality. Apart from that, gene therapy offers the potential of a lifetime cure, a better quality of life and freedom from various related morbidities. Theoretically, once gene therapy is administered, the affected individual will be asymptomatic with respect to haemophilia. There are still doubts with regards to long-term sustenance of the effects, unintended consequences or adverse effects and the costs of therapy. We aim to conduct this review in the hopes of answering some of the above questions, specifically in terms of the benefits and safety of gene therapy in comparison to standard treatment in people affected with haemophilia. At this stage, when only phase 1 and 2 studies have been performed on this subject, this review is aimed at being a comprehensive resource about the available best evidence and status of ongoing and future research and trials. This is an update of a previously published Cochrane Review (Sharma 2014).

\section{OBJECTIVES}

To evaluate the safety and efficacy of gene therapy in the treatment of people affected with haemophilia A or haemophilia B.

\section{METHODS}

\section{Criteria for considering studies for this review}

\section{Types of studies}

Randomised or quasi-randomised clinical trials including controlled clinical trials.

\section{Types of participants}

Individuals with haemophilia A or B of all ages who do not have inhibitors to factor VIII or IX.

\section{Types of interventions}

Gene therapy (with or without standard treatment) compared with the current standard treatment (regular or long-acting factor replacement given on an on-demand schedule or prophylactically) or other 'curative' treatment such as stem cell transplantation.

\section{Types of outcome measures}

\section{Primary outcomes}

1. Bleeding episode(s) (bleeding frequency, number of bleeding episodes per year, or as reported in the trial)

2. Factor VIII or IX supplementation requirement (frequency as reported in the trials)

3. Serious adverse events (resulting in death or life threatening complications, inpatient hospitalisation, significant or permanent disability, or one that requires additional intervention to prevent permanent damage or disability)

a. Evidence of clotting factor antibody development

b. Evidence of organ toxicity

c. Evidence of tumour development

\section{Secondary outcomes}

1. Measures of haemostasis

a. Clotting factor plasma levels

b. Activated partial thromboplastin time (aPPT)

c. International normalised ratio (INR)

d. Prothrombin time (PT)

2. Non-serious adverse events (any adverse event other than those mentioned above)

3. Joint damage (changes in: clinical joint function; orthopedic joint score; or radiologic joint score)

4. Quality of life (as measured by standardised instruments)

\section{Search methods for identification of studies}

\section{Electronic searches}

We searched the Cystic Fibrosis \& Genetic Disorders Group's Coagulopathies Trials Register using the terms: gene therapy AND haemophilia*.

The Coagulopathies Trials Register is compiled from electronic searches of the Cochrane Central Register of Controlled Trials (CENTRAL) (updated each new issue of the Cochrane Library) and weekly searches of MEDLINE and the prospective hand searching of a journal - Haemophilia. Unpublished work is identified by searching the abstract books of major conferences: the European Haematology Association (EHA) conference; the American Society of Hematology (ASH) conference; the British Society for Haematology Annual Scientific Meeting; the Congress of the World Federation of Hemophilia; the European Association for Haemophilia and Allied Disorders, the American Society of Gene and Cell Therapy (ASGCT) and the International Society on Thrombosis and Haemostasis. For full details of all searching activities for the register, please see the relevant section of the Cystic Fibrosis and Genetic Disorders Group Module.

Additionally, we directly searched PubMed, Embase and CENTRAL using a search strategy as described in appendices (Appendix 1; Appendix 2; Appendix 3).

We considered including trials irrespective of publication status, publication date or language. 
Date of the most recent search of the Cystic Fibrosis and Genetic Disorders Group's Coagulopathies Trials Register: 18 August 2016.

Date of the most recent search of PubMed, Embase, CENTRAL and any other resources as listed below: 02 December 2016.

\section{Searching other resources}

We searched the reference lists and contact authors of included trials, to identify any additional, potentially relevant trials for inclusion. We searched available clinical trial registers or meta registers for any ongoing trials, specifically in the following registers using the search term 'haemophilia' or 'hemophilia'.
- The WHO clinical trials register ICTRP (http://www.who.int/ ictrp/en/)

- ClinicalTrials.gov (http://www.clinicaltrials.gov/)

- Current Controlled Trials (http://controlled-trials.com/)

\section{Data collection and analysis}

Two authors (VS and AS) undertook searches for eligible studies (see Figure 1). We were unable to identify any randomised controlled trials eligible for inclusion in this review. As a result, we were unable to perform the selection process and data analyses as planned. In the future, if we identify any trials and include them in the review, we will adhere to the methods described in detail below in the remainder of this section. 
Figure 1. PRISMA flow diagram showing process of study selection.

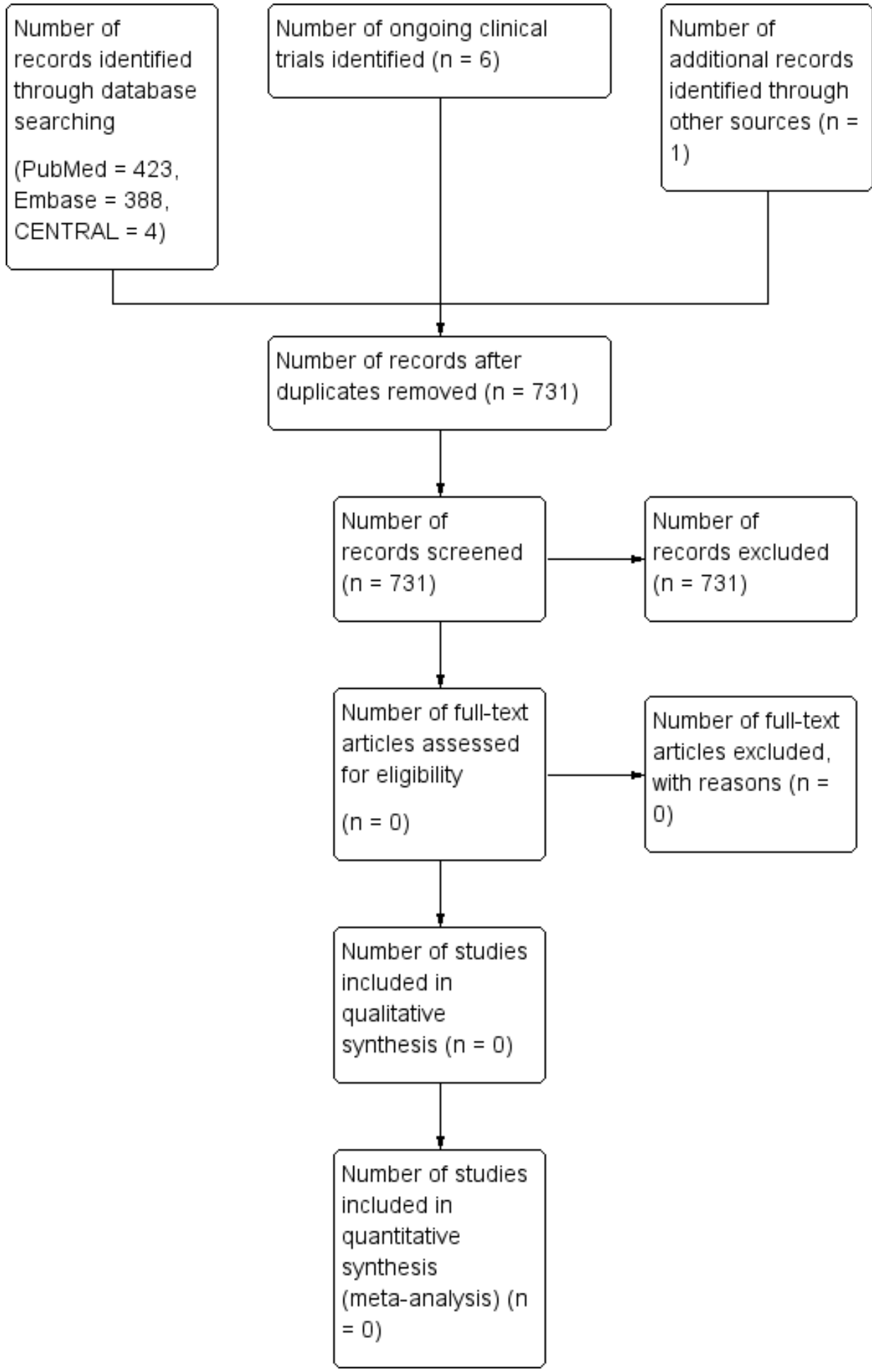

\section{Selection of studies}

Search results from all sources will be put together in a reference manager software and duplicates will be excluded. Two review authors (AS and MEM) will then independently screen the search results using titles and abstracts to exclude irrelevant trials. We shall classify the remaining trials into included, excluded and those awaiting classification, using the predefined criteria for selecting trials. For those trials awaiting classification, we will evaluate the report(s) and then make the judgment regarding inclusion or exclusion. If we are not able to make a judgment from the report(s), we shall attempt to contact the trial authors and make the classification once we have obtained sufficient information. We will resolve any disagreements by a consensus meeting with the third author (VS). We shall clearly document the reasons for exclusion. 
We will also scrutinise each trial report to ensure that multiple publications from the same trial are included only once and all such reports will be linked to the original trial report in the reference list of included trials.

\section{Data extraction and management}

Two review authors (AS and MEM) will independently extract the data from the trials considered for inclusion using a structured data extraction form. We will resolve any disagreements by discussion and, in any cases where there are persisting disagreements; we will seek arbitration by another author (UR).

We will extract the following data.

1. General information: title; authors; source; country; year of publication; setting.

2. Trials characteristics: design; method of randomisation; allocation concealment; blinding of outcome assessors.

3. Patients: inclusion and exclusion criteria; underlying disease; sample size; baseline characteristics of patients; losses to follow up.

4. Interventions: type of vector; dose.

5. Additional treatment: immunosuppressive therapy.

6. Outcomes: as mentioned above (primary and secondary outcomes).

If the full text versions do not provide sufficient information, we will contact the corresponding author for further details.

\section{Assessment of risk of bias in included studies}

Two review authors (AS and MEM) will independently assess the risk of bias of the included trials on the basis of generation of the randomisation sequence, allocation concealment, blinding (of the participants, personnel and outcome assessors), attrition bias, and selective outcome reporting. We will assign judgments on the above domains of risk of bias into high, low and unclear, based on table $8.5 \mathrm{~d}$ of the Cochrane Handbook for Systematic Reviews of Interventions (Higgins 2011a). We aim to resolve any disagreements by referring to the trial report and, if necessary, through arbitration with two other authors (VS and UR).

\section{Measures of treatment effect}

Different types of data will be analysed as below.

\section{Rate data}

When an outcome is measured in terms of rates we shall perform the analysis using rate ratios (RR) with their 95\% confidence intervals $(95 \% \mathrm{Cl})$.

\section{Continuous data}

When outcome data are continuous, we shall extract means and standard deviations (SD). If the outcomes are reported using different continuous scales we shall use the standardized mean difference (SMD) and their associated 95\% Cls to perform the analysis.

\section{Dichotomous data}

We shall extract the number of events and the total number of people reporting outcomes and analyse them using risk ratios (RR) and their associated $95 \% \mathrm{Cl}$.

\section{Unit of analysis issues}

\section{Trials with multiple treatment groups}

In cases of trials with multiple treatment groups we shall ensure that a participant group is not represented more than once in the same analysis. We shall either combine groups to make pair wise comparisons if possible, or exclude groups by making a decision on which group is most clinically relevant and extract the data only for that group.

\section{Cluster-randomised trials}

We do not expect to find cluster-randomised trials for this intervention. However, if we do find such trials which report data adjusted for design effect, we shall use the information as such. If the effect estimates are not adjusted, we shall extract the intra cluster correlation coefficient (ICC), if provided in the trial report, or contact the authors for the same and adjust the effect estimate for the design effect.

\section{Cross-over trials}

We do not expect to find cross-over trials as successful gene therapy is irreversible.

\section{Dealing with missing data}

We will contact the primary investigators if information is missing or if there are unclear outcome data, summary data or individual data. We shall extract data for the number of people randomised and the number analysed for each outcome. If there is a difference, we shall calculate the percentage change and report it as loss to follow up.

For missing data for dichotomous outcomes, we will perform a per protocol analysis on the data.

For outcomes with continuous data that are missing SDs, we will either calculate these from other available data such as standard errors (SE), or will impute them, if possible. We shall impute SDs on the basis of SDs for the same outcome using the same scale, from within our review or from other similar studies, reviews or metaanalyses (Higgins 2011b).

\section{Assessment of heterogeneity}

We shall visually examine a forest plots for overlapping confidence intervals and use the $\mathrm{Chi}^{2}$ test for homogeneity and the $\mathrm{I}^{2}$ test for heterogeneity, to estimate the contribution of true inter trial variability. The $\mathrm{Chi}^{2}$ statistic will be considered to represent significant heterogeneity at a level of $10 \%$ significance ( $P$ value $<$ 0.1 ). We will use an $I^{2}$ statistic value of less than $40 \%$ to represent mild heterogeneity that can be ignored; $30 \%$ to $60 \%$ to represent moderate and $50 \%$ to $90 \%$ significant heterogeneity, the reasons for which we shall try to explore by subgroups. We shall consider an 12 value of $75 \%$ or greater as substantial heterogeneity, in which case we shall not perform meta-analysis.

\section{Assessment of reporting biases}

We shall assess for publication bias using funnel plots (provided that there are at least 10 included trials in an analysis). When funnel plots show asymmetry, we shall consider publication bias as a possible reason (Sterne 2011). 


\section{Data synthesis}

We shall attempt to pool results only when there is no clinical heterogeneity and when there is no substantial statistical heterogeneity $(12<75 \%)$. When heterogeneity is present we shall analyse it using the random-effects model. If we have studies reporting effect estimates without summary data for each group, we shall attempt to pool the effect estimates using generic inverse variance method. We shall attempt to pool data of outcomes reported at the same point of follow up across trials. If this is not possible we shall pool trial data at one, two and five years.

If meta-analysis is not possible, we shall perform a descriptive, qualitative critical appraisal of the outcome information from the included trials.

\section{Subgroup analysis and investigation of heterogeneity}

In case we observe moderate or substantial heterogeneity in any of the analyses, we plan to explore the possible causes by undertaking the following subgroup analyses:

1. age (previously treated paediatric patients, previously untreated paediatric patients and adult patients, paediatric patients will be defined as those less than 18 years of age);

2. type of haemophilia (haemophilia A, haemophilia B);

3. gene therapy technique (ex vivo or in vivo transduction);

4. vector used (different types of vectors used, e.g. AAV8 viral vector),

5. hepatitis $\mathrm{C}$ status (positive, negative).

We would like to compare, if possible, all outcomes following gene therapy in younger versus older individuals. This is because older individuals undergoing gene therapy may already have significant co-morbidities from ongoing disease process. Method and site of cellular transduction can also vary the adverse event profile and if there are adequate numbers of trials available then we will do a subgroup analysis comparing the different methods. If one particular approach seems to have more adverse effects than the other then we will conduct the meta-analysis both with and without the given approach and report the result separately.

\section{Sensitivity analysis}

We will perform sensitivity analyses to assess the robustness of the review's results by repeating the analysis after excluding studies with clearly a high risk of bias (e.g. inadequate allocation of concealment, randomisation, or blinding, or high attrition or missing data), provided there are sufficient numbers of studies to include.

\section{RES U L T S}

\section{Description of studies}

No trials were found that were eligible for inclusion in this review.

\section{Results of the search}

The search strategies used as described in the appendices below yielded a total of 731 unique records. Records were screened by their title, or if unclear, by the abstract, to identify if they matched the inclusion criteria. None of the records matched the inclusion criteria for this review and hence were not included.

\section{Risk of bias in included studies}

No trials were eligible for inclusion in the review.

\section{Effects of interventions}

No trials were eligible for inclusion in the review.

\section{DISCUSSION}

Gene therapy involves making a change in the genetic material of certain target cells in the patient's body by means of a vector (usually viruses) or gene editing in such a way that the changed genetic material is functional and produces an adequate end product which corrects the underlying defect of the disease. In haemophilia, recombinant genetic material is introduced into the target cells or defective genes are modified to produce clotting factors deficient in the disease. The comprehensive search used in this review identified no eligible trials, and hence at this point there is no robust evidence to support or refute the effectiveness and safety of gene therapy for people with haemophilia.

Although no randomised controlled trials were found that are eligible for inclusion in this review which compared gene therapy to factor replacement head-to-head, there are several phase 1 and 2 studies evaluating various factor IX gene therapy products underway (NCT01687608; NCT01620801; NCT00979238; NCT02484092; NCT02396342; NCT02618915). These studies are currently enrolling or have enrolled and are following individuals with haemophilia B, studying the safety or efficacy of various viral vector-transgene constructs for the replacement of the defective factor IX gene. All these studies have used adeno-associated virus (AAV) serotypes for transfection of the gene product in the human body. Depending upon the transgene delivered by the vector in these studies, factor IX levels ranging from $2 \%$ to greater than $50 \%$ have been reported in the study participants (George 2016). An increase in factor IX level more than $50 \%$ is certainly enough to alleviate the symptoms of haemophilia, an increase of mere $2 \%$ also does improve the phenotype and reduces the requirement of factor replacement. Although AAV is not known to cause disease in humans, the group from University College of London and St. Jude Children's Research Hospital has reported that at least four out of six participants of the trial who received the higher dose of the viral vector, had a transient increase in their markers of liver inflammation (Nathwani 2011; Nathwani 2014; NCT00979238).Similar transient elevation of liver enzymes, which resolved with prophylactic steroid therapy was also reported in another study using a different serotype of AAV (NCT02396342; Miesbach 2016). Recently a phase 1 study (NCT02695160) that utilizes a novel gene editing technique using zinc finger nucleases has also started recruiting participants. If successful, this technique will be a promising alternative to the approach of introducing a transgene to cure haemophilia, as discussed above.

A single phase $1 / 2$ clinical trial studying the efficacy and safety of escalating doses of BMN270, an AAV gene therapy product for haemophilia A recently concluded enrolling participants (NCT02576795). In their preliminary results, the investigators reported up to more than $150 \%$ factor VIII activity correction with a single infusion of the viral vector (Pas 2016). This is the first report of a successful gene therapy product for haemophilia A in humans.

Despite this initial success of these techniques long-term safety of these methods is yet to be ascertained. As a new paradigm 
in the treatment of haemophilia, gene therapy will first need to undergo long-term follow-up studies to demonstrate sustained efficacy and affordability. Long-term safety of the gene therapy vectors in terms of insertional mutagenesis or host immune response and tolerance, will have to be demonstrated before gene therapy becomes widely used. Availability of newer factor concentrates, with much longer half-lives, requiring less frequent infusions as compared to the existing factor concentrates, are changing the standard of patient care already (Carcao 2014; Konkle 2015; Young 2015; Powell 2013; Santagostino 2016). New drugs have been developed which have shown promise in the treatment of cystic fibrosis and Duchenne and Becker muscular dystrophy by preventing premature termination of gene translation due to nonsense mutations (which produce premature stop codons) (NCT00803205; NCT00847379). Similar drugs may be used for treating haemophilia caused by nonsense mutations in the future (NCT00947193). These new therapies, in conjunction with other advances in the field of haemophilia, may obviate the need for gene therapy. Conversely, gene therapy may prove to be a safe, affordable, convenient and sustainable treatment for patients with haemophilia. Future studies will hopefully form the basis for an objective assessment of the benefits versus the risks of gene therapy over the current standard of care in haemophilia.

Currently, there is no information contained within any of the databases we searched on gene therapy for haemophilia, so no objective discussion on the risks, benefits or otherwise can be made.

\section{AUTHORS' CONCLUSIONS}

\section{Implications for practice}

No randomised controlled trials of gene therapy for haemophilia were found for inclusion in this review. A few first-in-human studies of gene therapy in haemophilia have been conducted with limited short-term success; however, long-term safety and efficacy data are lacking. It is yet to be known whether one-time infusion of these viral vectors is successful in 'curing' this disease or several infusions over a period of time are needed to control the symptoms. Further, the safety and economic burden of this technique vis-a-vis current standard of care will only be known once the previous questions are answered. We are currently unable to draw any conclusions regarding the effects of gene therapy for haemophilia.

\section{Implications for research}

This systematic review has identified the need for further welldesigned and long-term clinical trials to assess the feasibility, benefits and risks of gene therapy for haemophilia. The primary outcome for these trials would be reduction in symptoms or factor infusion requirement for the haemophilia patients. Also, because of the potential side effects of using viruses as vectors in gene therapy, long-term follow up studies of existing vectors and further progress in new non-viral vector development is necessary. Hence, this review identifies areas of research involving safety, efficacy, longterm follow up and economic burden of gene therapy compared to current standard of care.

\section{ACKNOWLEDGEMENTS}

We would like to thank the South Asian Cochrane Network \& Centre for providing logistical and technical support. We are also grateful to the Cochrane Cystic Fibrosis and Genetic Disorders Group for their support throughout the development of this review. Lastly, we would also like to acknowledge Jessica Neely, MD and Sasank Kalipatnapu, MBBS for their contributions to the original review (Sharma 2014). 


\section{RE F E R E N C E S}

\section{Additional references}

\section{Anson 1984}

Anson DS, Choo KH, Rees DJ, Giannelli F, Gould K, Huddleston JA, et al. The gene structure of human antihaemophilic factor IX. EMBO Journal 1984;3:1053-60.

\section{Aronstam 1993}

Aronstam A, Congard B, Evans DI, Gazengel CF, Herberg U, Hill FG, et al. HIV infection in haemophilia--a European cohort. Archives of Disease in Childhood 1993;68(4):521-4. [PUBMED: 8099271]

\section{Bi 1995}

Bi L, Lawler AM, Antonarakis SE, High KA, Gearhart JD, Kazazian HH Jr. Targeted disruption of the mouse factor VIII gene produces a model of haemophilia A. Nature Genetics 1995;10(1):119-21.

\section{Brinkhous 1968}

Brinkhous KM, Shanbrom E, Roberts HR, Webster WP, Fekete L, Wagner RH. A new high-potency glycine-precipitated antihemophilic factor (AHF) concentrate. Treatment of classical hemophilia and hemophilia with inhibitors. JAMA 1968;205(9):613-7.

\section{Carcao 2014}

Carcao M. Changing paradigm of prophylaxis with longer acting factor concentrates. Haemophilia 2014;20 Suppl 4:99-105. [PUBMED: 24762284]

\section{Castaman 2008}

Castaman G. Desmopressin for the treatment of haemophilia. Haemophilia 2008;14 Suppl 1:15-20.

\section{Choo 1982}

Choo KH, Gould KG, Rees DJ, Brownlee GG. Molecular cloning of the gene for human anti-haemophilic factor IX. Nature 1982;299(5879):178-80.

\section{Evatt 2006}

Evatt BL. The tragic history of AIDS in the hemophilia population, 1982-1984. Journal of Thrombosis and Haemostasis 2006;4(11):2295-301.

\section{George 2016}

George LA, Sullivan S, Teitel J, Cuker A, Luk A, Wright F, et al. Preliminary results of a phase $1 / 2$ trial of SPK-9001, a hyperactive FIX variant delivered by a novel capsid, demonstrate consistent factor IX activity levels at the lowest dose cohort. Haemophilia 2016;22(Suppl 4):151-2. [DOI: 10.1111/hae.13068]

\section{Gill 1983}

Gill JC, Menitove JE, Wheeler D, Aster RH, Montgomery RR. Generalized lymphadenopathy and T cell abnormalities in hemophilia A. Journal of Pediatrics 1983;103(1):18-22. [PUBMED: 6223133]

\section{Gitschier 1984}

Gitschier J, Wood WI, Goralka TM, Wion KL, Chen EY, Eaton DH, et al. Characterization of the human factor VIII gene. Nature 1984;312:326-30.

\section{Goedert 1989}

Goedert JJ, Kessler CM, Aledort LM, Biggar RJ, Andes WA, White GC 2nd, et al. A prospective study of human immunodeficiency virus type 1 infection and the development of AIDS in subjects with hemophilia. New England Journal of Medicine 1989;321(17):1141-8. [PUBMED: 2477702]

\section{Hacein-Bey-Abina 2003}

Hacein-Bey-Abina S, Von Kalle C, Schmidt M, McCormack MP, Wulffraat N, Leboulch P, et al. LMO2-associated clonal T cell proliferation in two patients after gene therapy for SCID-X1. Science 2003;302(5644):415-9.

\section{Higgins 2011a}

Higgins JPT, Altman DG, Sterne JAC, on behalf of the Cochrane Statistical Methods Group and the Cochrane Bias Methods Group. Chapter 8: Assessing risk of bias in included studies. In: Higgins JPT, Green S (editors). Cochrane Handbook for Systematic Reviews of Interventions Version 5.1.0 [updated March 2011]. The Cochrane Collaboration, 2011. Available from www.cochrane-handbook.org.

\section{Higgins 2011b}

Higgins JPT, Deeks JJ, Altman DG. Chapter 16: Special topics in statistics. In: Higgins JPT, Green S (editors). Cochrane Handbook of Systematic Reviews of Interventions. Version 5.1 [updated March 2011]. The Cochrane Collaboration, 2011. Available from www.cochrane-handbook.org.

\section{High 2011}

High KA. Gene therapy for haemophilia: a long and winding road. Journal of Thrombosis and Haemostasis 2011;9 Suppl 1:2-11.

\section{Iorio 2011}

Iorio A, Marchesini E, Marcucci M, Stobart K, Chan AK. Clotting factor concentrates given to prevent bleeding and bleedingrelated complications in people with hemophilia A or B. Cochrane Database of Systematic Reviews 2011, Issue 9. [DOI: 10.1002/14651858.CD003429.pub4; PUBMED: 21901684]

\section{Kasper 1972}

Kasper CK, Kipnis SA. Hepatitis and clotting-factor concentrates. JAMA 1972;221(5):510. [PUBMED: 5067966]

\section{Konkle 2015}

Konkle BA, Stasyshyn O, Chowdary P, Bevan DH, Mant T, Shima M, et al. Pegylated, full-length, recombinant factor VIII for prophylactic and on-demand treatment of severe hemophilia A. Blood 2015;126(9):1078-85. [DOI: 10.1182/ blood-2015-03-630897; PUBMED: 26157075] 


\section{Leissinger 2001}

Leissinger C, Becton D, Cornell C Jr, Cox Gill J. High-dose DDAVP intranasal spray (Stimate) for the prevention and treatment of bleeding in patients with mild haemophilia A, mild or moderate type 1 von Willebrand disease and symptomatic carriers of haemophilia A. Haemophilia 2001;7(3):258-66.

\section{Makris 1990}

Makris M, Preston FE, Triger DR, Underwood JC, Choo QL, Kuo G, et al. Hepatitis $C$ antibody and chronic liver disease in haemophilia. Lancet 1990;335(8698):1117-9. [PUBMED: 1971863]

\section{Manco-Johnson 2007}

Manco-Johnson MJ, Abshire TC, Shapiro AD, Riske B, Hacker MR, Kilcoyne R, et al. Prophylaxis versus episodic treatment to prevent joint disease in boys with severe hemophilia. New England Journal of Medicine 2007;357(6):535-44.

\section{Manno 2003}

Manno CS, Chew AJ, Hutchison S, Larson PJ, Herzog RW, Arruda VR, et al. AAV-mediated factor IX gene transfer to skeletal muscle in patients with severe hemophilia B. Blood 2003; Vol. 101 , issue 8:2963-72.

\section{Manno 2006}

Manno CS, Pierce GF, Arruda VR, Glader B, Ragni M, Rasko JJ, et al. Successful transduction of liver in hemophilia by AAV-Factor IX and limitations imposed by the host immune response. Nature Medicine 2006;12(3):342-7.

\section{Mannucci 1977}

Mannucci PM, Ruggeri ZM, Pareti FI, Capitanio A. 1-Deamino-8$d$-arginine vasopressin: a new pharmacological approach to the management of haemophilia and von Willebrands' diseases. Lancet 1977;1(8017):869-72. [PUBMED: 67283]

\section{Miesbach 2016}

Miesbach W, Tangelder M, Klamroth R, Schutgens R, Coppens M, Kampmann $\mathrm{P}$, et al. Updated results from a dose escalating study in adult patients with haemophilia B treated with AMT-060 (AAV5-hFIX) gene therapy. Haemophilia 2016;22(Suppl 4):151-2. [DOI: 10.1111/hae.13068]

\section{Miller 2005}

Miller DG, Trobridge GD, Petek LM, Jacobs MA, Kaul R, Russell DW. Large-scale analysis of adeno-associated virus vector integration sites in normal human cells. Journal of Virology 2005;79(17):11434-42.

\section{Mingozzi 2011}

Mingozzi F, High KA. Therapeutic in vivo gene transfer for genetic disease using AAV: progress and challenges. Nature Reviews. Genetics 2011;12(5):341-55.

\section{Nakai 2005}

Nakai H, Wu X, Fuess S, Storm TA, Munroe D, Montini E, et al. Large-scale molecular characterization of adeno-associated virus vector integration in mouse liver. Journal of Virology 2005;79(6):3606-14.

\section{Nathwani 2004}

Nathwani AC, Davidoff AM, Tuddenham EG. Prospects for gene therapy of haemophilia. Haemophilia 2004;10(4):309-18.

\section{Nathwani 2006}

Nathwani AC, Gray JT, Ng CY, Zhou J, Spence Y, Waddington SN, et al. Self-complementary adeno-associated virus vectors containing a novel liver-specific human factor IX expression cassette enable highly efficient transduction of murine and nonhuman primate liver. Blood 2006;107(7):2653-61.

\section{Nathwani 2011}

Nathwani AC, Tuddenham EG, Rangarajan S, Rosales C, Mclntosh J, Linch DC, et al. Adenovirus-associated virus vectormediated gene transfer in hemophilia B. New England Journal of Medicine 2011;365(25):2357-65. [PUBMED: 22149959]

\section{Nathwani 2014}

Nathwani AC, Reiss UM, Tuddenham EG, Rosales C, Chowdary P, McIntosh J, et al. Long-term safety and efficacy of factor IX gene therapy in hemophilia B. New England Journal of Medicine 2014;371(21):1994-2004. [DOI: 10.1056/NEJMoa1407309; PUBMED: 25409372]

\section{NCT00803205}

NCT00803205. Study of ataluren (PTC124 ${ }^{\mathrm{TM}}$ ) in cystic fibrosis. http://clinicaltrials.gov/ct2/show/study/NCT00803205 (accessed 1 September 2014). [NCT00803205]

\section{NCT00847379}

NCT00847379. Phase $2 \mathrm{~b}$ extension study of ataluren (PTC124) in Duchenne/Becker muscular dystrophy (DMD/BMD). http://clinicaltrials.gov/ct2/show/NCT00847379 (accessed 1 September 2014). [NCT00847379]

\section{NCT00947193}

NCT00947193. Study of ataluren (PTC124 ${ }^{\circledR}$ ) in hemophilia A and B. http://clinicaltrials.gov/ct2/show/NCT00947193 (accessed 1 September 2014). [NCT00947193]

\section{NCT00979238}

NCT00979238. An open label dose-escalation study of a self complementary adeno-associated viral vector (scAAV 2/8-LP1-hFIXco) for gene transfer in hemophilia B. http:// clinicaltrials.gov/show/NCT00979238 (accessed 26 April 2014). [NCT00979238]

\section{NCT01620801}

NCT01620801. A Phase 1 safety study in subjects with severe hemophilia B (factor IX deficiency) using a single-stranded, adeno-associated pseudotype 8 viral vector to deliver the gene for human factor IX. http://clinicaltrials.gov/show/NCT01620801 (accessed 26 April 2014). [NCT01620801]

\section{NCT01687608}

NCT01687608. A phase 1/2 open-label, single ascending dose trial of a self-complementing optimized adeno-associated virus serotype 8 factor IX gene therapy (AskBio009) in adults with hemophilia B. http://clinicaltrials.gov/show/NCT01687608 (accessed 26 April 2014). [NCT01687608] 


\section{NCT02396342}

NCT02396342. Trial of AAV5-hFIX in Severe or Moderately Severe Hemophilia B. https://clinicaltrials.gov/ct2/show/NCT02396342 (accessed 05 November 2016). [NCT02396342]

\section{NCT02484092}

NCT02484092. A Gene Therapy Study for Hemophilia B. https://clinicaltrials.gov/ct2/show/NCT02484092 (accessed 05 November 2016). [NCT02484092]

\section{NCT02576795}

NCT02576795. Gene Therapy Study in Severe Haemophilia A Patients. https://clinicaltrials.gov/ct2/show/NCT02576795 (accessed 05 November 2016). [NCT02576795]

\section{NCT02618915}

NCT02618915. Safety and Dose Finding Study of DTX101 (AAVrh10FIX) in Adults With Moderate/Severe to Severe Hemophilia B. https://clinicaltrials.gov/ct2/show/NCT02618915 (accessed 05 November 2016). [NCT02618915]

\section{NCT02695160}

NCT02695160. Ascending Dose Study of Genome Editing by the Zinc Finger Protein (ZFP) Therapeutic SB-FIX in Severe Hemophilia B. https://clinicaltrials.gov/ct2/show/NCT02695160 (accessed 05 November 2016). [NCT02695160]

\section{NHF 2013}

National Hemophilia Foundation. Fast Facts. http:// www.hemophilia.org/NHFWeb/MainPgs/MainNHF.aspx? menuid=259\&contentid=476 (accessed 26 April 2014).

\section{Palmer 1989}

Palmer TD, Thompson AR, Miller AD. Production of human factor IX in animals by genetically modified skin fibroblasts: potential therapy for hemophilia B. Blood 1989;73(2):438-45.

\section{Pas 2016}

Pas J, Wong W, Rangarajan S, Wilde J, Perry D, Madan B, et al. Interim results of an open-label, phase $1 / 2$ study of BMN 270, an AAV5- FVIII gene transfer in severe hemophilia A. Haemophilia 2016;22(Suppl 4):151-2. [DOI: 10.1111/hae.13068]

\section{Ponder 2008}

Ponder KP, Srivastava A. Walk a mile in the moccasins of people with haemophilia. Haemophilia 2008;14(3):618-20.

\section{Ponder 2011}

Ponder KP. Merry christmas for patients with hemophilia B. New England Journal of Medicine 2011;365(25):2424-5.

\section{Powell 2003}

Powell JS, Ragni MV, White GC 2nd, Lusher JM, HillmanWiseman C, Moon TE, et al. Phase 1 trial of FVIII gene transfer for severe hemophilia A using a retroviral construct administered by peripheral intravenous infusion. Blood 2003;102(6):2038-45.

\section{Powell 2013}

Powell JS, Pasi KJ, Ragni MV, Ozelo MC, Valentino LA, Mahlangu JN, et al. Phase 3 study of recombinant factor IX FC fusion protein in hemophilia B. New England Journal of Medicine
2013;369(24):2313-23. [DOI: 10.1056/NEJMoa1305074; PUBMED: 24304002]

\section{Roth 2001}

Roth DA, Tawa NE Jr, O'Brien JM, Treco DA, Selden RF, Factor VIII Transkaryotic Therapy Study Group. Nonviral transfer of the gene encoding coagulation factor VIII in patients with severe hemophilia A. New England Journal of Medicine 2001;344(23):1735-42.

\section{Santagostino 2010}

Santagostino E, Mancuso ME. Venous access in haemophilic children: choice and management. Haemophilia 2010;16 Suppl 1:20-4. [DOI: 10.1111/j.1365-2516.2009.02156.x; PUBMED: 20059565]

\section{Santagostino 2016}

Santagostino E, Martinowitz U, Lissitchkov T, PanPetesch B, Hanabusa H, Oldenburg J, et al. Long-acting recombinant coagulation factor IX albumin fusion protein (rIX-FP) in hemophilia B: results of a phase 3 trial. Blood 2016;127(14):1761-9. [DOI: 10.1182/blood-2015-09-669234; PUBMED: 26755710]

\section{Sterne 2011}

Sterne JAC, Egger M, Moher D, on behalf of the Cochrane Bias Methods Group. Chapter 10: Addressing reporting biases. In: Higgins JPT, Green S (editors). Cochrane Handbook forSystematic Reviews of Interventions Version 5.1 [updated March 2011]. The Cochrane Collaboration, 2011. Available from www.cochrane-handbook.org.

\section{Toole 1984}

Toole JJ, Knopf JL, Wozney JM, Sultzman LA, Buecker JL, Pittman DD, et al. Molecular cloning of a CDNA encoding human antihaemophilic factor. Nature 1984;312(5992):342-7.

\section{Tuddenham 2012}

Tuddenham E. Gene therapy for haemophilia B. Haemophilia 2012;18 Suppl 4:13-7.

\section{VandenDriessche 1999}

VandenDriessche T, Vanslembrouck V, Goovaerts I, Zwinnen H, Vanderhaeghen ML, Collen D, et al. Long-term expression of human coagulation factor VIII and correction of hemophilia A after in vivo retroviral gene transfer in factor VIII-deficient mice. Proceedings of the National Academy of Sciences of the United States of America 1999;96(18):10379-84.

\section{Webster 1965}

Webster WP, Roberts HR, Thelin GM, Wagner RH, Brinkhous KM. Clinical use of a new glycine-precipitated antihemophilic fraction. American Journal of the Medical Sciences 1965;250(6):643-51.

\section{WFH 2013}

World Federation of Hemophilia. Annual Report 2013. http:// www1.wfh.org/publications/files/pdf-1578.pdf (accessed 02 December 2016). 


\section{Wong 2011}

Wong T, Recht M. Current options and new developments in the treatment of haemophilia. Drugs 2011;71(3):305-20.

\section{Xu 2003}

Xu L, Gao C, Sands MS, Cai SR, Nichols TC, Bellinger DA, et al. Neonatal or hepatocyte growth factor-potentiated adult gene therapy with a retroviral vector results in therapeutic levels of canine factor IX for hemophilia B. Blood 2003;101(10):3924-32.

\section{Young 2015}

Young G, Mahlangu J, Kulkarni R, Nolan B, Liesner R, Pasi J, et al. Recombinant factor VIII Fc fusion protein for the prevention and treatment of bleeding in children with severe hemophilia $A$. Journal of Thrombosis and Haemostasis 2015;13(6):967-77. [DOI: 10.1111/jth.12911; PUBMED: 25912075]

\section{References to other published versions of this review \\ Sharma 2014}

Sharma A, Easow Mathew M, Sriganesh V, Neely JA, Kalipatnapu S. Gene therapy for haemophilia. Cochrane Database of Systematic Reviews 2014, Issue 11. [DOI: 10.1002/14651858.CD010822.pub2]

\section{APPENDICES}

\section{Appendix 1. PubMed search strategy}

$\# 1$ randomized controlled trial [pt]

$\# 2$ controlled clinical trial [pt]

\#3 randomized [tiab]

\#4 placebo [tiab]

\#5 drug therapy [sh]

\#6 randomly [tiab]

\#7 trial [tiab]

\#8 groups [tiab]

\#9 \#1 OR \#2 OR \#3 OR \#4 OR \#5 OR \#6 OR \#7 OR \#8

$\# 10$ animals $[\mathrm{mh}]$ NOT humans $[\mathrm{mh}]$

\#11 \#9 NOT \#10

$\# 12$ (gene or genetic) and (therapy or therapies) and (hemophilia* or haemophilia*)

\#13 \#11 AND \#12

Note: Lines \#1-\#11 are the Cochrane Highly Sensitive Search Strategy for identifying randomised trials in MEDLINE: sensitivity- and precision-maximizing version (2008 revision); PubMed format.

PubMed searched via NCBI PubMed web site http://www.ncbi.nlm.nih.gov/pubmed/

\section{Appendix 2. Embase search strategy}

\#1 [animals]/lim NOT [humans]/lim

\#2 'randomized controlled trial'/de OR 'controlled clinical trial'/de OR 'controlled study'/de OR randomized:ab,ti OR placebo:ab,ti OR randomly:ab,ti OR trial:ab,ti OR groups:ab,ti

\#3 \#2 NOT \#1

\#4 'gene therapy'/exp OR (gene:ab,ti OR genetic:ab,ti AND (therapy:ab,ti OR therapies:ab,ti OR 'drug therapy'/exp OR 'diseases'/exp/ dm_dt,dm_dr)) AND (hemophilia*:ab,ti OR haemophilia*:ab,ti OR 'hemophilia'/exp)

\#5 \#3 AND \#4

Note: EMBASE was searched via EMBASE/Elsevier including records from 1974- present.

\section{Appendix 3. CENTRAL search strategy}

(gene or genetic) and (therapy or therapies) and (hemophilia* or haemophilia*)

Note: CENTRAL (Issue 3 of 12, March 2014) searched via the Cochrane Library (http://crso.cochrane.org/)

WHAT'S NEW

\begin{tabular}{lll}
\hline Date & Event & Description \\
\hline 16 December 2016 & $\begin{array}{l}\text { New citation required but conclusions } \\
\text { have not changed }\end{array}$ & Minor changes have been made throughout this update. \\
\hline
\end{tabular}




\begin{tabular}{lll}
\hline Date & Event & Description \\
\hline 16 December 2016 & New search has been performed & $\begin{array}{l}\text { A new search of the Cochrane Cystic Fibrosis and Genetic Disor- } \\
\text { ders Group's Haemoglobinopathies Trials Register did not identi- } \\
\text { fy any potentially relevant trials for inclusion in this update. }\end{array}$ \\
\hline
\end{tabular}

\section{CONTRIBUTIONS OF AUTHORS}

\begin{tabular}{|c|c|}
\hline \multicolumn{2}{|l|}{ Roles and responsibilities } \\
\hline Task & $\begin{array}{l}\text { Who will undertake this } \\
\text { task? }\end{array}$ \\
\hline Protocol stage: draft the protocol & AS, MEM \\
\hline Review stage: select which trials to include $(2+1)$ & AS, MEM, VS \\
\hline Review stage: extract data from trials $(2+1)$ & AS, MEM, UR \\
\hline Review stage: enter data into RevMan & AS \\
\hline Review stage: carry out the analysis & AS, MEM \\
\hline Review stage: interpret the analysis & AS, MEM, UR \\
\hline Review stage: draft the final review & AS, UR \\
\hline Update stage: update the review & AS, MEM, VS, UR \\
\hline
\end{tabular}

\section{DECLARATIONS OF INTEREST}

Akshay Sharma: none known.

Manu Easow Mathew: none known.

Vasumathi Sriganesh: none known.

Ulrike M Reiss: none known.

Vasumathi Sriganesh: is the founder and Hon CEO of Quality Medical (QMed) Knowledge Foundation, a not for profit Trust in Mumbai, India. Through the Foundation she and her colleagues offer training and support for literature search, referencing and writing activities to health sciences students and professionals.

\section{SOURCES OF SUPPORT}

\section{Internal sources}

- South Asian Cochrane Network \& Centre, India.

\section{External sources}

- Cochrane Cystic Fibrosis \& Genetic Disorders Group, UK.

- National Institute for Health Research, UK.

This systematic review was supported by the National Institute for Health Research, via Cochrane Infrastructure funding to the Cochrane Cystic Fibrosis and Genetic Disorders Group. 
INDEX TERMS

\section{Medical Subject Headings (MeSH)}

${ }^{\star}$ Genetic Therapy; Hemophilia A [ ${ }^{\star}$ therapy]; Hemophilia B [*therapy]

\section{MeSH check words}

Humans 